\title{
Universidade da Integração Internacional da Lusofonia Afro-Brasileira (UNILAB)
}

A Universidade da Integração Internacional da Lusofonia Afro-Brasileira (UNILAB) é uma das mais recentes universidades federais brasileiras. A sua trajetória inicia-se em 2008, no cenário dos debates intelectuais e políticos sobre cooperação solidária sul-sul e ações afirmativas. Assim, países membros da Comunidade dos $\mathrm{Pa}$ íses de Língua Portuguesa (CPLP) e Secretaria de Ensino Superior ( $\mathrm{SeSu}$ ) do MEC instalam uma comissão de estudo para avaliar a viabilidade e elaborar o projeto de criação da instituição. Ao longo de dois anos, essa comissão realizou levantamentos e estudos a respeito de temas e problemas sociais, políticos, culturais e tecnológicos comuns ao Brasil e aos países da CPLP, especialmente os africanos, e elaborou o projeto que subsidiou a lei no 12.289 de 20 de julho de 2010, que regulamentou a criação da UNILAB.

Uma vez criada, a UNILAB foi inserida no projeto de expansão da rede pública de educação superior brasileira, implantado pelo MEC em 2007 com o objetivo principal de promover a descentralização e interiorização do ensino superior no país, por meio da criação de, ao menos, uma instituição federal em cidades-polo do entorno regional. Essa posição decorre da decisão de interferir em um círculo vicioso em que a baixa escolaridade da população se reflete na pobreza econômica da localidade/regiáo e vice-versa. A expansão da educação superior no Brasil tinha e tem como eixo norteador o Programa de Apoio a Planos de Re-estruturação e
Expansão das Universidades Federais (Reuni). Foi como ação específica do Reuni no estado do Ceará que, em 25 de maio de 2011, ocorreu a instalação efetiva do campus sede da UNILAB (Campus da Liberdade), em Redenção, município da região do Maciço de Baturité.

A UNILAB nasce, assim, atendendo a duas grandes diretrizes da política do MEC para o ensino superior no Brasil. De um lado, a da expansão por meio da interiorizaçáo, visando recuperar o sentido público e compromisso social da educação superior pela via da expansão com qualidade e inclusão. De outro, a da integração internacional, em especial a promoção da cooperação sul-sul na perspectiva da cooperação solidária, valorizando e apoiando o potencial de colaboração e aprendizagem entre países.

Esse potencial se traduz no corpo discente formado por estudantes do Brasil, Angola, Cabo Verde, Guiné-Bissau, Moçambique, São Tomé e Príncipe e Timor Leste, distribuídos nos seguintes cursos de graduação: Agronomia, Administração Pública (na modalidade à distância), Bacharelado em Humanidades, Ciências da Natureza e Matemática, Enfermagem, Engenharia de Energias e, Letras (português). A universidade também oferece cursos de especialização, tal como "Especialização em História e Cultura Africana e Afro-brasileira”, com base na Lei 10639/03 e voltado para professores da rede pública municipal. Recentemente, em setembro deste ano, a universidade teve 
372 | Universidade da InTEGração InTERnACional da LuSOFonia Afro-Brasileira

seu primeiro mestrado aprovado pela CAPES: mestrado interdisciplinar em Sociobiodiversidade e Tecnologias Sustentáveis. O corpo docente, também reflexo dessa pluralidade, é formado por professores doutores brasileiros e estrangeiros que estão cimentando o caminho do ensino, pesquisa e extensáo na universidade.

Exemplo disso foi a formação neste ano do Grupo de Pesquisa ORITÁ - Espaços, Identidades, Memórias e Pensamento Complexo com o objetivo de investigar processos e dinâmicas relacionados aos espaços, às identidades, às memórias e ao pensamento complexo. A formação do grupo foi uma iniciativa dos professores Rodrigo Ordine, Jacqueline Brito Pólvora, Vera Rodrigues e Vânia Gico, membros do Instituto de Humanidades e Letras.

O grupo atua nas seguintes linhas de pesquisa:

\section{Cidades e Dinâmicas Sócio-Culturais}

Objetivo: Propóe investigar as relações dos sujeitos sociais com o espaço urbano. Aborda os processos de transformação das cidades e seus efeitos no cotidiano das pessoas. Analisa políticas urbanas e as possíveis tensóes e/ou conflitos entre a maneira de viver a/na cidade e os projetos de transformação deste espaço. Coordenação: Profa Dra. Jacqueline Brito Pólvora.

\section{Estudos do Pensamento Complexo e Trans- disciplinaridade}

Objetivo: Produzir conhecimento complexo, teórico e empírico, sobre práticas e produtos culturais, sobre os grupamentos sociais que as englobam e sobre as variadas formas de registros, orais e escritos, fundamentadas na compreensão transdisciplinar e na ecologia dos saberes. Coordenação: Profa Dra. Vânia Gico.

\section{Identidades e Políticas Públicas}

Esta linha de pesquisa propóe-se, na interface das relaçóes entre Estado e sociedade, a produzir estudos voltados para os processos que envolvem pleitos por reconhecimento identitário, direitos e a adoção de políticas públicas direcionadas a determinados segmentos sociais. A produção intelectual abarca as discussões teóricas sobre cidadania, direitos humanos, diversidade, relaçóes étnico-raciais, desigualdades fundadas em pertencimentos identitários e multiculturalismo. Coordenação: Prof ${ }^{a}$ Dra. Vera Rodrigues.

\section{Memórias, Traumas e Construçáo da Realidade}

Propóe-se à análise de narrativas autobiográficas (orais e escritas) e das inserçóes, em maior ou menor grau, de traços de resiliência, de falsas memórias, de memórias ressentidas e de traumas, entendidos não somente como frutos de experiências radicais, mas como resultados dos embates com uma realidade cotidiana em constante construção. Envolve, portanto, a literatura de testemunho, os relatos de vida, as autobiografias, os ego-escritos e as entrevistas orais. Coordenação: Prof. Dr. Rodrigo Ordine

A proposta de criação do grupo se insere no contexto mais geral da Unilab, cujas diretrizes voltam-se para a inserção e integração de diferentes realidades, oriundas de diversos contextos culturais, religando e tecendo redes de conhecimento. O próprio nome do grupo, Oritá, reflete essa interdisciplinaridade de conhecimentos. Oritá é uma palavra do Iorubá, língua africana muito falada na região da África Subsariana, que significa "encruzilhada". Uma metáfora para explicar a ligação entre profissionais de ciências disciplinares diferentes no grupo de pesquisa, Sociologia, Antropologia, Linguística e Literatura. 